\title{
Production Division Compliance Audit On Standard Operating Procedures Pt. Pusaka Marmer Indah Raya (Pumarin)
}

\author{
Aisyah Margaretta ${ }^{1}$, Tommy Kuncara ${ }^{2 *}$ \\ ${ }^{1,2}$ Faculty of Economics Gunadarma University \\ Jl. Margonda Raya No. 100, Depok 16424, West Java \\ ${ }^{*}$ Corresponding author: \\ Email:Tommy kuncara@staff.gunadarma.ac.id
}

\begin{abstract}
.
This study aims to determine whether the employees of the production division have complied with the standard operating procedures set by PT PUSAKA MARMER INDAH RAYA (PUMARIN) properly or not. The method used in this scientific research is a qualitative descriptive analysis technique, which is a research technique that analyzes, describes, and summarizes various conditions, situations from various data collected in the form of the results of interviews or observations about the problems studied that occur in the field. The results of the research that the authors found were that there were two points that were still not adhered to by the production division employees, such as not smoking in all areas of the work environment, and correctly understanding the materials that would be used for production.
\end{abstract}

Keywords: Standard Operating Procedures, Compliance Audit, PT. Pusaka Marmer Indah Raya (PUMARIN)

\section{INTRODUCTION}

In today's business world, many companies engaged in services, trade, and manufacturing experience increasing competition. Not only domestic companies are facing this competition, but global competition. Various kinds of challenges will arise starting from social challenges, technological advances, quality, and services in attracting the attention of consumers. Requires innovation in maintaining the sustainability of a company. Many companies are also experiencing bankruptcy due to a lack of worker loyalty in handling their work. Having employees or workers who are skilled, focused, agile, work hard, optimistic, and also have high motivation in their work is an important asset for the company. Having the right strategy and human resources is one solution in dealing with every problem that exists in the company. Every company certainly has a goal to be achieved, in order to realize this goal the company must pay attention to many factors supporting the company, one of which is employees. Employees can determine the progress or decline of a company. With the presence of competent, skilled, focused, and agile employees as well as adequate human resources, the company has more value in carrying out the right strategy for sure. Employees themselves are the most important factor in every company, by having the help of many and competent employees, the company can build high-value human resources.In the company employees themselves have a very important function and position.

Therefore, in carrying out their duties, employees are required to carry out their work in accordance with the provisions imposed by the company. Operational standards are guidelines for employees in carrying out their duties, with operational standards employees become more focused and make human resources more professional to achieve company goals, besides standard operating procedures can be used as employee references as written guidelines to move and encourage performance to improve performance. achieving goals.Good operational standards can also be a communication tool for one employee to another so that the work is more focused and well completed. Every company should have a standard such as the implementation of Standard Operating Procedures (SOP).Employees need to be self-aware in meeting standard operating procedures (SOPs). Because employees' adherence to standard operating procedures can provide many positive benefits for the company and will also make it easier for employees to complete their duties. Satisfactory service and quality gradewill reflect a good image for the company.However, sometimes 
the reality on the ground is very different from the prevailing procedure. Real work in the field is often found that standard operating procedures (SOPs) are not followed. Not complying with it will cause some problems. Even more fatal if standard operating procedures (SOPs) are not complied with, affecting other regulations as well. So it is feared that later employee awareness of the importance of standard operating procedures (SOP) will fade because they are accustomed to violating regulations.

One of the negative impacts that will emerge is that the quality of the products produced will decrease and the level of trust from consumers also decreases. Other impacts will also emerge because employees who do not comply with standard operating procedures (SOPs) will become disorganized.

Therefore, before the problem gets more complicated,will be a controlneeded. Control can be done by checking or assessing (audit) employee compliance with standard operating procedures (SOP). This compliance audit method is the first step to make improvements in a non-compliance problem with standard operating procedures. A compliance audit is a gradual and continuous improvement step and can find and fix problems that arise before these problems become more serious. Examination of employee compliance with standard operating procedures (SOP) can see and examine employee compliance, how well employees comply with standard operating procedures (SOP).A compliance audit can be one step in finding and fixing problems that arise before they become more serious. Employee compliance audit can also see if the employee is already following the standard operating procedures (SOP) applies. The author wants to test the compliance of employees in the production division to the Standard Operating Procedures at PT. Heirloom Marble Indah Raya. The author sees that there are employee performances that are not in accordance with applicable procedures so that there are several errors that result in the resulting product being not good, a small example caused by human error is not cutting the marble properly and the goods have been sent abroad. Disobedience of employees to applicable procedures can result in the quality of the products produced decreasing and also lowering the level of consumer confidence in the company.

\section{LITERATURE REVIEW Compliance Audit}

According to Valery (2011), acompliance auditis an audit that aims to provide an overview of the implementation activities or the implementation of work systems (business processes) that apply to all corporate activities. That is why the scope of compliance audit is referred to as critical process audit view, because it makes all processes in the system the main object to be checked. The results of the compliance audit are then reported to a higher person or party within an organization being audited and not given to parties outside the company. Management is usually the party with the most interest in the results of the compliance audit, compared to other parties. Therefore, most of the audit work of this kind can usually be carried out by auditors working in the relevant organizational unit. However, compliance audits can also be done by auditors appointed external organizations in the audit, such as auditors and public accounting firms auditing firm who perform independent audits of the financial statements.

\section{Standard Operating Procedures}

Standard Operating Procedures are standards of activities that must be carried out in sequence to complete a job and if adhered to it will have a good impact, for example, good coordination, better working relationships and also clarifying the rights and duties of an employee.Wibowo (2010:67) reveals that standard operating procedures have several criteria, namely, effective and efficient, systematic, consistent, as work standards, easy to understand, complete, written and open to change/flexibility.

\section{METHOD}

\section{Research object The}

object of this research is PT. Heirloom Marble Indah Raya. PT. Pusaka Marmer Indah Raya is a marble company in Indonesia with its address at Ruko Imperial Walk, South Tangerang City, Banten. This company is engaged in marble manufacturing and already has several mines in Indonesia.

\section{Types of Data and Data Sources The}

type of data used in this study is qualitative data. Qualitative data is data that is descriptive in the 
form of a description, and the data cannot be used as numbers. The data used in this research is in the form of direct information collection conducted at PT. Heirloom Marble Indah Raya which is located at Ruko Imperial Walk, South Tangerang City, Banten.The source of data in this study is primary data. Primary data is data obtained directly by researchers in the field through respondents by means of observation, interviews and questionnaires. The primary data obtained in this study were obtained through interviews.

\section{Data Collection Techniques Data}

collection techniques used, among others:

\section{InterviewInterview}

Techniquestechnique is an attempt to collect some information by asking a number of questions orally and in writing. This interview was conducted with one of the employees of PT. Pusaka Marmer Indah Raya (PUMARIN)methods

\section{Observation Techniques Observation}

techniques are one of the data collectionused to collect research data through direct observation and recording the facts that actually occurred. The purpose of the observation was to observe directly whether the employees of the production division of PT. The Indah Raya Marble Heritage complies with the SOP or not.

\section{Documentation Techniques Documentation}

techniques are the collection of data obtained from records owned by the company. This technique is used to obtain data about documents. records, regulations

standard operating procedureof the company, as well as files related to compliance audits. The author collects data on standard operating procedures at PT. Heirloom Marble Indah Raya.

\section{Literature Study Techniques Literature}

study technique is one way of collecting data from references, journals, books, notes, and company policy regulations.

\section{Analysis}

Techniques The data analysis technique used is a qualitative descriptive analysis technique, which is a research technique that analyzes, describes, and summarizes various conditions, situations from various data collected in the form of the results of interviews or observations about the problems studied that occur in the field.

\section{DISCUSSION RESULTS}

\section{Discussion of}

PT. Pusaka Marmer Indah Raya is one of the largest marble companies in Indonesia. With the presence of several superior products, PT. Pusaka Marmer Indah Raya has succeeded in supplying marble to various regions both overseas and abroad, and also as an exporter of Indonesian marble throughout the world. This achievement is also due to the cooperation of the employees of PT. Heirloom Marble Indah Raya.The work spirit of the employees of PT. Heirloom Marble Indah Raya, made PT. Pusaka Marmer Indah Raya has succeeded in creating a high quality marble that can compete on a national and international scale.PT. Pusaka Marmer Indah Raya also provides consultation in advance for customers who want to buy their products.

With the presence of consulting services provided by them, PT. Pusaka Marmer Indah Raya hopes that there will be no misunderstanding in the selection of marble that is suitable for customers. In compliance audit activities at PT. The Indah Raya Marble Heritage is carried out by third parties or external parties. The arrival of external parties in this compliance audit effort, employees from PT. Pusaka Marmer Indah Raya was not aware of the presence of the audit team. The presence of the audit team is only known by the HRD of PT. Heirloom Marble Indah Raya.After completing all activities in the factory, the employees of PT. Heirloom Marble Indah Raya carries out cleaning activities, and puts all the tools that have been used into the storage area provided by PT. Heirloom Marble Indah Raya. Every day, employees who are Muslim carry out prayer activities together and pray together for the sake of safety and smooth working.

\section{Summary of Research Results The}

following will present a summary of research results in the form of work activities in the Standard 
Operating Procedures (SOP) of PT. Heirloom Marble Indah Raya (PUMARIN). The results of research conducted by the author can be seen in the following table

Table 4.3. Results of Standard Operating Procedures Compliance PT. Pusaka Marmer Indah Raya

\begin{tabular}{|c|c|c|c|c|c|}
\hline NO & $\begin{array}{l}\text { ACTIVITY } \\
\text { BASED SOP }\end{array}$ & & $\begin{array}{c}\text { CONSEQUENTI } \\
\text { AL }\end{array}$ & COMPLIANT & $\begin{array}{c}\text { NOT } \\
\text { COMPLIANT }\end{array}$ \\
\hline & $\begin{array}{l}\text { Start abriefing } \\
\text { before starting } \\
\text { work }\end{array}$ & $\begin{array}{l}\text { Getting workers } \\
\text { Know what } \\
\text { To do or done }\end{array}$ & $\begin{array}{l}\text { Minimizing } \\
\text { mistakes while } \\
\text { doingthe work } \\
\text { later }\end{array}$ & $\sqrt{ }$ & \\
\hline & $\begin{array}{l}\text { Wear the } \\
\text { uniform } \\
\text { provided by } \\
\text { the company }\end{array}$ & $\begin{array}{l}\text { As the identity } \\
\text { of the company }\end{array}$ & - & $\sqrt{ }$ & \\
\hline & $\begin{array}{l}\text { No smoking } \\
\text { in all areas of } \\
\text { the work } \\
\text { environment }\end{array}$ & $\begin{array}{l}\text { avoiding } \\
\text { accidents that } \\
\text { may becaused } \\
\text { bya cigarette } \\
\text { butt that has not } \\
\text { been turned off } \\
\text { properly and } \\
\text { also avoid } \\
\text { inconveniences }\end{array}$ & $\begin{array}{l}\text { order no to } \\
\text { disturb other } \\
\text { workers and also } \\
\text { work activities } \\
\text { ongoing }\end{array}$ & & $\sqrt{ }$ \\
\hline
\end{tabular}

\begin{tabular}{|c|c|c|c|}
\hline & NON & & \\
\hline $\begin{array}{l}\text { Wear a mask } \\
\text { typesrespirator } \\
\text { N95 while in the } \\
\text { area of working } \\
\text { environment }\end{array}$ & $\begin{array}{l}\text { Avoiding } \\
\text { problems } \\
\text { healthcaused by } \\
\text { inhaling } \\
\text { dustparticles } \\
\text { or metal danger } \\
\text { and damage the } \\
\text { lungs }\end{array}$ & $\begin{array}{l}\text { order not } \\
\text { their health } \\
\text { impaired workers } \\
\text { from inhaling } \\
\text { dustparticles or } \\
\text { metal that are } \\
\text { harmful }\end{array}$ & $\sqrt{ }$ \\
\hline $\begin{array}{l}\text { Wear a helmet / } \\
\text { cover head } \\
\text { whilethe doing } \\
\text { job }\end{array}$ & $\begin{array}{l}\text { Avoid debris } \\
\text { boulders and } \\
\text { also hot sun }\end{array}$ & $\begin{array}{l}\text { Protecting the } \\
\text { injury to the } \\
\text { head, and also } \\
\text { increase the } \\
\text { visibility of } \\
\text { workers }\end{array}$ & $\sqrt{ }$ \\
\hline $\begin{array}{l}\text { Use gloves } \\
\text { when doing } \\
\text { work }\end{array}$ & $\begin{array}{l}\text { Avoid } \\
\text { accidents } \\
\text { workcaused } \\
\text { by sharp tools } \\
\text { or machines } \\
\text { whoseis } \\
\text { constructionco } \\
\text { mplicated with } \\
\text { teeth sharp }\end{array}$ & $\begin{array}{l}\text { Hand } \\
\text { protected at while } \\
\text { working on } \\
\text { something thatthe } \\
\text { haspotential to } \\
\text { cause injury to } \\
\text { the hands }\end{array}$ & $\sqrt{ }$ \\
\hline
\end{tabular}




\begin{tabular}{|c|c|c|c|c|}
\hline $\begin{array}{l}\text { Wear boots } \\
\text { when entering } \\
\text { thearea work }\end{array}$ & $\begin{array}{l}\text { Avoid } \\
\text { slippery roads } \\
\text { or boulders }\end{array}$ & $\begin{array}{l}\text { workers more } \\
\text { flexibility in } \\
\text { moving to } \\
\text { improvethe } \\
\text { effectiveness of } \\
\text { production } \\
\text { activities }\end{array}$ & $\sqrt{ }$ & \\
\hline $\begin{array}{l}\text { Check back all } \\
\text { production } \\
\text { equipment } \\
\text { before use }\end{array}$ & $\begin{array}{l}\text { Checking back } \\
\text { all the tools } \\
\text { production must } \\
\text { be done by each } \\
\text { worker before } \\
\text { starting work }\end{array}$ & $\begin{array}{l}\text { To avoid the tool } \\
\text { is broken or not } \\
\text { functioning } \\
\text { properly and also } \\
\text { avoid accidents } \\
\text { that may occur } \\
\text { due to a tool that } \\
\text { is not functioning } \\
\text { properly }\end{array}$ & $\sqrt{ }$ & \\
\hline $\begin{array}{l}\text { Memah ami } \\
\text { with the right } \\
\text { materials are } \\
\text { used for } \\
\text { production }\end{array}$ & - & - & & $\sqrt{ }$ \\
\hline $\begin{array}{l}\text { Working of } \\
\text { products in } \\
\text { accordance with } \\
\text { the conditions } \\
\text { provided }\end{array}$ & $\begin{array}{l}\text { Workers must } \\
\text { know the work } \\
\text { activities }\end{array}$ & $\begin{array}{l}\text { Works regularly } \\
\text { according to the } \\
\text { provisions given } \\
\text { and }\end{array}$ & $\sqrt{ }$ & \\
\hline
\end{tabular}

\begin{tabular}{|c|c|c|c|}
\hline company & $\begin{array}{l}\text { productionthat } \\
\text { has been in } \\
\text { charge } \\
\text { the company }\end{array}$ & $\begin{array}{l}\text { Also producedin } \\
\text { accordance and it } \\
\text { increases trust } \\
\text { consumers } \\
\text { against } \\
\text { companies }\end{array}$ & \\
\hline $\begin{array}{l}\text { Coordinate with } \\
\text { the quality } \\
\text { control to } \\
\text { perform a final } \\
\text { check before } \\
\text { goods are } \\
\text { distributed }\end{array}$ & $\begin{array}{l}\text { part of the } \\
\text { production must } \\
\text { be coordinated } \\
\text { with the quality } \\
\text { control to avoid } \\
\text { product not } \\
\text { good }\end{array}$ & $\begin{array}{l}\text { items to be } \\
\text { distributed } \\
\text { already passed } \\
\text { the final check } \\
\text { and is almost } \\
\text { certain no product } \\
\text { not good or } \\
\text { defective }\end{array}$ & $\sqrt{ }$ \\
\hline $\begin{array}{l}\text { Handing over } \\
\text { the goods } \\
\text { produced to the } \\
\text { warehouse }\end{array}$ & $\begin{array}{l}\text { Thegoods } \\
\text { finishedmust be } \\
\text { immediately } \\
\text { submitted to the } \\
\text { warehouse so } \\
\text { that they are not } \\
\text { damaged and } \\
\text { are not mixed } \\
\text { with the new } \\
\text { goods to be } \\
\text { processed. }\end{array}$ & $\begin{array}{l}\text { Goods are not } \\
\text { scattered and can } \\
\text { be directly } \\
\text { calculated by } \\
\text { parts factory }\end{array}$ & $\sqrt{ }$ \\
\hline
\end{tabular}

From the Compliance Audit SOP (Standard Operating Procedure) Production Department PT. Pusaka Marmer Indah Raya (PUMARIN) that:

1. Conduct a briefing before doing work (Already according to SOP) 
2. Wear uniforms that have been provided by the company (Already in accordance with SOP)

3. No smoking in all areas of the work environment (Not in accordance with SOP)

4. 4 Wearing a mask when in the work area (Already in accordance with SOP)

5. Wearing a helmet/head cover when doing work (Already in accordance with SOP)

6. Using gloves when doing work (Already in accordance with SOP)

7. Wearing boots when entering the area work (Already in accordance with SOP)

8. Recheck all production equipment before use (Already according to SOP)

9. Correctly understand the material used for production (Not in accordance with SOP)

10. Work on products in accordance with the provisions provided by the company (Already in accordance with SOP) )

11.Coordinate with thedepartment quality control to carry out a final check before the goods are distributed (Already in accordance with the SOP)

12.Submit the goods produced to the warehouse. (Already in accordance with SOP)

In the section on Understanding correctly the materials used for production are not obeyed by some employees because it is difficult to memorize the names of the materials to be used, while not smoking in all areas of the work environment is still not obeyed because there are still many workers who smoke in the work area during break

\section{CONCLUSIONS AND RECOMMENDATIONS \\ Conclusion}

From the results of the analysis of

Standard Operating Procedures at PT. Pusaka Marmer Indah Raya (PUMARIN) the author can conclude that the application of Standard Operating Procedures that has been complied with from the 12 points that apply only 2 points that are not obeyed by employees in the Standard Operating Procedures (SOP), namely at points 3 and 9.No smoking in all areas work. Where workers should be prohibited from smoking in all work areas because it can disturb the comfort of other workers and endangerwork activities, ongoinghowever, some workers are still seen smoking during breaks. And in the section to understand correctly the material used for production, in this section it is difficult for employees to obey because of the difficulty of the name of the material to be used.

\section{Suggestions}

Based on the conclusions and also the discussion above, as the author will provide some suggestions that might be useful for the company and also for further research, namely:

\section{For the Company}

- As an internal party, more supervision should be carried out on employee performance and also ready to give sanctions if there are employees or workers who violate the regulations in the work environment

- The company needs to provide more knowledge of the materials to be produced so that workers have a better understanding of the materials to be used so thatdo not production errorsoccur

- The company needs to provide a special smoking room for employees

\section{For Academics}

Further research i. s expected to involve external supervisors in addition to relying on internal data, because external supervisors are very effectively used to

audit employee compliance levels

\section{REFERENCES}

[1] Arens, Alvin A. And Loebecke, James K. (2005). Auditing An Integrated Approach, Eighth Edition. New Jersey: Prentice Hall Inc.

[2] Arens, AA, RJ Elder, and MS Beasley. (2004). Auditing and Verification Services.Edition Ninth: Indonesian Edition: PT. Index. 
[3] Arens, AA, RJ Elder, and MS Beasley. (2013). AuditServices and Assurance: AnApproach Integrated (Amir Abadi Jusuf, Translator). Jakarta: Four Salemba.

[4] Lukman Nul Hakim. 2016. Employee Compliance Audit Against Standard Operating Procedures Yamaha Workshop CV. ANDI JAYA MOTOR Cakung,East Jakarta.University Gunadarrma.

[5] Mulyadi. 2002. Auditing, Book One and Book Two, Sixth Edition. Jakarta: Four Salemba.

[6] Nafisa Qoulbi. 2020. Compliance Audit of PT Sigma Jaya Mitra Abadi in the Division Salesmanagainst Standard Operating Procedures (SOP). GunadarmaUniversity

[7] Okka Vitalokha. 2018. Implementation ofAudit ComplianceinDivision Productionof PT.CHEF INDOCAN PANDAAN.University of Surabaya.

[8] Rio Prasetyo. 2018. Compliance Audit at the Teller Division of Bank BCA KCP Harapan Indah Unit. Gunadarma University.

[9] Rudi M Tambunan. 2013, Standard Operating Procedures (SOP), Jakarta: Maiestas Publishing. Standard Operating Procedures of PT. Heirloom Marble Indah Raya. 2018.

[10] Sukrisno Agoes. 2004, Auditing (Accountant Examination) by the Public Accounting Firm. Third Edition. Jakarta:Institute

[11] Publishingof the Faculty of Economics, University of Indonesia (FEUI).

[12] Sunarto. 2003. Auditing. Yogyakarta: Guide.

[13] Zulaikha. 2006. Effect of Gender Interaction, Task Complexity and Auditor Experience

[14] on Audit Judgment. Journal National Symposium of the 9 PadangAccounting. 